\title{
Reaksi Pasar Sebelum dan Sesudah Internet Financial Reporting
}

\author{
Rendi Satria dan Supatmi \\ Fakultas Ekonomika dan Bisnis Universitas Kristen Satya Wacana \\ Jl. Diponegoro 52-60 Salatiga - Indonesia 50711 \\ Email: patmie@staff.uksw.edu
}

\begin{abstract}
ABSTRAK
Penelitian ini bertujuan untuk mengetahui perbedaaan reaksi pasar sebelum dan sesudah internet financial reporting (IFR) yang diukur dengan volume perdagangan saham dan abnormal return. Sampel yang digunakan terdiri dari 181 perusahaan yang terdaftar di BEI pada tahun 2011. Volume perdagangan saham dan abnormal return diuji menggunakan uji beda Wilcoxon Signed Test untuk mengetahui perbedaan sebelum dan sesudah publikasi IFR. Temuan pada penelitian ini menunjukkan terdapat perbedaan reaksi pasar sebelum dan sesudah publikasi IFR, baik yang diukur dengan volume perdagangan saham dan abnormal return. Perusahaan yang menerapkan IFR memiliki rata-rata volume perdagangan saham dan abnormal return lebih besar sesudah publikasi IFR.
\end{abstract}

Kata Kunci: Internet financial reporting, volume perdagangan saham, abnormal return.

\begin{abstract}
This research aims to determine the differences market reaction before and after the internet financial reporting (IFR) as measured by trading value activity and abnormal return. The sample used consist of 181 listed companies in BEI period 2011. Trading value activity and abnormal return tested by Wilcoxon Signed Test to determine the difference before and after IFR publication. The results of this research indicate that there are differences market reaction before and after IFR publication, which were measured by trading value activity and abnormal return. The companies which use IFR will have higher average of trading value activity and abnormal return after IFR publication.
\end{abstract}

Keywords: Internet financial reporting, trading value activity, abnormal return.

\section{PENDAHULUAN}

Jumlah pengguna internet di Indonesia saat ini semakin meningkat. Pada tahun 2011, jumlah pengguna internet di Indonesia diestimasi mencapai 55.000 .000 atau $22,4 \%$ dari populasi penduduk, meningkat dibandingkan tahun 2010 dengan jumlah pengguna internet sebesar $16,1 \%$ dari keseluruhan populasi penduduk (internetworldstats.com). Internet dapat digunakan untuk setiap aplikasi bisnis yang melibatkan komunikasi data, termasuk komunikasi di dalam perusahaan maupun dengan lingkungan (McLeod 2007). Internet mempunyai beberapa karakteristik dan keunggulan seperti memfasilitasi penyebaran informasi yang berguna untuk pengambilan keputusan, tepat waktu, memiliki akses global dan berbiaya rendah (Ashbaugh et al. 1999). Dengan keunggulan internet tersebut dan didukung meningkatnya pengguna internet menyebabkan organisasi bisnis telah banyak memanfaatkan situs internet untuk menunjang kegiatan bisnisnya.

Akhir-akhir ini, organisasi bisnis mengoptimalisasi keunggulan internet untuk pelaporan informasi yang berhubungan dengan investor. Pada pendataan tahun 2008, hampir sekitar $80 \%$ perusahaan yang terdaftar di bursa telah memanfaatkan media internet untuk tujuan hubungan ke calon investor dan investor (Wibisono 2011). Internet menyediakan suatu bentuk unik pengungkapan sukarela perusahaan yang memungkinkan perusahaan dapat menyediakan informasi secara cepat kepada masyarakat luas (Abdelsalam et al. 2007). Media internet atau website kini tidak hanya dimanfaatkan perusahaan untuk menawarkan produk atau jasa yang dihasilkan, namun juga 
dimanfaatkan untuk menyajikan laporan keuangan yang populer disebut Internet Financial Reporting (IFR).

Pengungkapan informasi keuangan dalam website perusahaan (Internet Financial ReportingIFR) merupakan suatu bentuk pengungkapan sukarela yang dipraktekkan oleh berbagai perusahaan (Hargyantoro 2010). Praktek IFR yang bersifat sukarela semakin disadari perusahaan bukan lagi menjadi sebuah keunggulan namun menjadi sebuah kebutuhan. Perusahaan tentu memahami bahwa informasi keuangan sangat menentukan pengambilan keputusan para investor. Wibisono (2011) berpendapat IFR menjawab kebutuhan akan sistem pelaporan keuangan yang fleksibel, mudah diakses, cepat dan terpercaya sedangkan sistem pelaporan berbasis kertas (paper-based) sudah dianggap tidak memenuhi kebutuhan tersebut.

Manfaat yang didapatkan dengan mempublikasikan informasi kinerja keuangan melalui IFR antara lain memiliki cakupan luas karena dapat diakses siapa pun dengan menggunakan media internet. Manfaat lainnya adalah IFR mampu menimbulkan biaya yang lebih hemat dibandingkan laporan keuangan yang menggunakan kertas. IFR mampu mengurangi biaya pencetakan dan distribusi terkait dengan laporan keuangan tahunan dan triwulanan (Ashbaugh et al. 1999). Manfaat tersebut semakin didukung dengan fakta bahwa calon investor dan investor memiliki minat yang tinggi untuk memanfaatkan IFR sebagai sumber informasi yang akan dipakai dalam pengambilan keputusan mereka (Wibisono 2011).

Berangkat dari fenomena tersebut, beberapa penelitian telah menguji tentang IFR. Chariri dan Lestari (2005) meneliti praktik IFR di perusahaan yang terdaftar di Bursa Efek Jakarta pada tahun 2005 dan menganalisis faktor-faktor yang mempengaruhi IFR. Hasil penelitiannya menemukan bahwa faktor-faktor seperti ukuran perusahaan, likuiditas, leverage, reputasi auditor dan umur listing perusahaan berpengaruh terhadap praktik IFR.

Almilia (2009) mengeksplorasi penggunaan website pada perusahaan go publik di Indonesia. Penelitian ini mengukur kualitas isi (content) informasi Financial and Sustainability Reporting pada website perusahaan. Hasil penelitian menemukan bahwa dari 343 perusahaan, sebanyak 213 perusahaan yang telah memiliki website dan 115 perusahaan diantaranya mengungkapkan laporan keuangan melalui media internet, dengan tingkat pengungkapan yang bervariasi. Isi dari Financial Reporting meliputi komponen informasi keuangan seperti laporan neraca, rugi laba, arus kas, perubahan posisi keuangan serta laporan keberlanjutan perusahaan.
Penelitian-penelitian tersebut masih berfokus terhadap faktor-faktor dan isi dari IFR. Sedangkan penelitian tentang hubungan IFR terhadap saham masih terbatas. Penelitian yang menguraikan pengaruh IFR terhadap saham, antara lain Lai et al. (2010) yang menemukan bahwa perusahaan yang menerapkan IFR dengan tingkat transparansi informasi yang lebih tinggi cenderung menghasilkan abnormal return yang lebih besar dan harga saham bergerak lebih cepat, dibandingkan dengan perusahaan yang tidak menerapkan IFR.

Hargyantoro (2010) menjelaskan pengaruh IFR dan tingkat pengungkapan informasi website terhadap frekuensi perdagangan saham. Semakin banyak informasi yang tersedia dan semakin cepat informasi itu tersedia akan mempemudah investor dalam mengevaluasi portofolio saham yang dimiliki. Informasi tersebut akan menciptakan penawaran dan permintaan oleh para investor yang berujung pada transaksi perdagangan saham.

Damayanti (2012) meneliti pengaruh IFR terhadap abnormal return dan frekuensi perdagangan saham antara perusahaan yang menerapkan IFR dan non-IFR. Hasil penelitian menemukan abnormal return, perusahaan yang menerapkan IFR berbeda signifikan dengan perusahaan yang tidak menerapkan IFR. Perusahaan yang menerapkan IFR memiliki abnormal return yang lebih tinggi daripada yang tidak menerapkan IFR, artinya IFR direspon oleh pasar. Hasil bertolak belakang terjadi pada pengujian variabel frekuensi perdagangan saham, perusahaan yang menerapkan IFR tidak berbeda secara signifikan dengan perusahaan yang tidak menerapkan IFR.

Dalam pasar modal, penggunaan IFR oleh perusahaan diharapkan akan memberikan dorongan bagi pasar untuk bereaksi (Ika dan Purwaningsih 2008). Budiman dan Supatmi (2008) berpendapat bahwa pasar akan bereaksi apabila laporan keuangan perusahaan mengandung sebuah informasi, yang dapat digunakan oleh investor sebagai dasar pertimbangan dalam membuat keputusan untuk melakukan investasi di pasar modal. Informasi yang dipublikasikan oleh emiten akan menimbulkan perubahan pada harga sekuritas dan transaksi perdagangan saham (Hartono 2008). Dari perubahan transaksi perdagangan tersebut, volume perdangangan dan abnormal return saham merupakan hal yang sangat menarik untuk diteliti lebih jauh. Volume perdagangan merupakan unsur kunci dalam melakukan prediksi terhadap pergerakan harga saham (Zamroni 2003 dalam Octavin 2008). Budiman dan Supatmi (2008) menyebutkan volume perdagangan merupakan indikator yang digunakan untuk menunjukan besarnya minat investor pada suatu saham. 
Semakin besar volume perdagangan berarti, saham tersebut sering ditransaksikan.

Berdasarkan uraian di atas, maka penelitian ini akan menguji pengaruh publikasi Internet Financial Reporting terhadap volume perdagangan dan abnormal return saham. Penelitian ini merupakan pengujian kembali dari penelitian yang dilakukan Hargyantoro (2010) dan Damayanti (2012). Perbedaannya adalah penelitian ini memberikan gambaran mengenai pengaruh IFR terhadap volume perdagangan dan abnormal return saham. Selain itu, berbeda dengan penelitian Hargyantoro (2010) yang menggunakan sampel perusahaan yang terdaftar dalam Indeks Kompas 100, sampel yang digunakan dalam penelitian ini adalah perusahaan yang terdaftar dalam Bursa Efek Indonesia tahun 2011 dan menerapkan IFR.

Perbedaan penelitian ini dengan penelitian yang dilakukan Damayanti (2012) adalah penelitian ini meneliti dengan metode uji beda sampel berpasangan, yaitu lima hari sebelum dan sesudah publikasi IFR. Variabel yang digunakan untuk mengukur reaksi pasar dalam penelitian ini adalah abnormal return dan volume perdagangan saham, berbeda dengan Damayanti (2012) yang memakai frekuensi perdagangan saham. Berbeda dengan Hargyantoro (2010) dan Damayanti (2012) yang meneliti perbedaan reaksi pasar antara perusahaan yang menerapkan IFR dengan yang tidak menerapkan IFR (Non-IFR), penelitian ini fokus pada perusahaan yang menerapkan IFR. Publikasi IFR yang direspon pasar dapat terlihat dengan nilai abnormal return saham dan volume perdagangan saham sebelum dan sesudah tanggal publikasi.

Penelitian ini bertujuan untuk meneliti dampak publikasi Internet Financial Reporting terhadap reaksi pasar yang di ukur menggunakan volume perdagangan dan abnormal return saham. Manfaat dari penelitian ini diharapkan investor memanfaatkan IFR dalam pengambilan keputusan di pasar modal sehingga memperoleh keuntungan. Penelitian ini juga diharapkan mendorong perusahaan untuk mempraktekkan IFR secara optimal sebagai sarana pelaporan informasi yang transparan dan cepat.

\section{Internet Financial Reporting (IFR)}

Internet Financial Reporting (IFR) adalah upaya pencantuman informasi keuangan perusahaan melalui internet atau website secara tepat waktu sesuai ketentuan pasar modal (Lai et al. 2010). Berdasarkan Keputusan Ketua Badan Pengawas Pasar Modal dan Lembaga Keuangan (Bapepam-LK) No. Kep-346/BL/2011 tanggal 5 Juli
2011 tentang Penyampaian Laporan Keuangan Berkala Emiten atau Perusahaan Publik, menyatakan: "Laporan keuangan tahunan wajib disampaikan kepada Bapepam dan LK dan diumumkan kepada masyarakat paling lambat pada akhir bulan ketiga setelah tanggal laporan keuangan tahunan".

Almilia (2009) menyatakan isi (content) Laporan Keuangan yang disajikan melalui website, meliputi Neraca, Laporan Laba Rugi, Laporan Arus Kas, Laporan Perubahan Ekuitas dan Catatan atas Laporan Keuangan. Berdasarkan penelitian Almilia (2009) dan Keputusan Bapepam LK, dapat disimpulkan penerapan IFR dalam konteks di Indonesia adalah perusahaan yang mempublikasikan laporan keuangan melalui website secara lengkap dan tepat waktu, maksimal tanggal 31 Maret tahun berikutnya setelah periode laporan keuangan.

Chandra (2008) dalam Hargyantoro (2010) menjelaskan langkah mengidentifikasikan cara penyajian melalui website, yaitu membuat duplikat laporan keuangan yang sudah dicetak ke dalam format electronic paper, mengkonversi laporan keuangan ke dalam format HTML, dan meningkatkan pencantuman laporan keuangan melalui website sehingga lebih mudah diakses oleh pihak yang berkepentingan daripada laporan keuangan dalam format cetak. Format yang dapat digunakan dalam mempresentasikan laporan keuangan melalui internet dapat berupa Portable Document Format (PDF), Hypertext Markup Language (HTML), Graphics Interchange Format (GIF), Joint Photographic Expert Group (JPEG), Microsoft Excel Spreadsheet, Microsoft Word, ZIP Files, Macromedia Flash Software, Real Networks Player Software, dan Macromedia Shockwave Software.

Menurut Wibisono (2011) keunggulan perusahaan yang menerapkan IFR antara lain frekuensi penyajian informasi yang lebih sering, biaya yang lebih hemat daripada perusahaan mencetak laporan keuangan dengan paper-based, penyajian lebih menarik, akses informasi oleh investor yang lebih cepat dan mudah. Adapun IFR memiliki kelemahan yaitu belum diaturnya IFR oleh badan profesional dapat membuat pembaca informasi IFR mentafsirkan informasi secara keliru karena format penyajian yang berbedabeda.

\section{Reaksi Pasar}

Penggunaan IFR oleh perusahaan diharapkan akan memberikan dorongan bagi pasar untuk bereaksi, dan reaksi pasar ini ditunjukkan oleh adanya perubahan harga saham, frekuensi per- 
dagangan saham perusahaan yang bersangkutan, dan return saham pada pasar (Ika dan Purwaningsih 2008). Budiman dan Supatmi (2008) menyatakan pengumuman yang mengandung informasi akan menunjukkan reaksi pasar dan perubahan harga yang dapat diukur dengan menggunakan abnormal return saham. Abnormal return (return tidak normal) adalah selisih antara return sesungguhnya yang terjadi dengan return ekspektasi (Hartono 2008). Sedangkan volume perdagangan atau Trading Volume Activity (TVA) adalah alat ukur yang digunakan untuk mengetahui bagaimana investor individual menggunakan laporan keuangan perusahaan sebagai dasar pengambilan keputusan dalam arti informasi tersebut dapat mempengaruhi investor dalam membuat keputusan perdagangan diatas keputusan perdagangan yang normal (Mardiyah dan Najib 2005). Volume perdagangan merupakan unsur kunci dalam melakukan prediksi terhadap pergerakan harga saham (Zamroni 2003 dalam Octavina 2008).

Berkaitan tentang distribusi informasi perusahaan melalui IFR, maka penelitian ini memakai teori pasar efisien. Fama (1970) dalam Hartono (2008) menyajikan tiga macam bentuk utama efisiensi pasar yaitu pasar bentuk lemah, setengah kuat dan kuat. Menurut Hartono (2008) pasar yang terdapat di Indonesia adalah bentuk setengah kuat. Pasar dikatakan setengah kuat apabila harga sekuritas secara penuh mencerminkan semua informasi yang dipublikasikan (laporan keuangan perusahaan emiten). Berdasarkan teori ini, tidak ada investor yang menggunakan informasi yang dipublikasikan untuk mendapatkan abnormal return dalam jangka waktu yang lama.

Teori lain yang berkaitan dengan penelitian ini adalah teori sinyal. Teori sinyal berperan dalam IFR karena teori sinyal menjelaskan alasan perusahaan menyajikan informasi. Alasan perusahaan untuk memberikan informasi adalah untuk mengurangi asimetri informasi antara perusahaan dan pihak luar karena perusahaan mengetahui lebih banyak mengenai perusahaan dan prospek yang akan datang dibanding pihak luar (Hargyantoro 2010). Selanjutnya Hargyantoro (2010) juga menyatakan bahwa pengungkapkan informasi keuangan dan non-keuangan secara sukarela di internet dapat menciptakan transparansi informasi yang lebih tinggi. Transparansi informasi mengurangi asimetri informasi antara pemilik (atau investor) dan manajemen.

Jika praktik IFR untuk mencapai transparansi informasi yang lebih besar, investor akan diberikan informasi yang relevan dan tepat waktu atau bahkan lebih awal mengenai perusahaan. Informasi tersebut akan membuat investor dapat lebih cepat bereaksi atau melakukan tindakan terhadap saham perusahaan yang membuat harga saham lebih cepat bergerak dan secara otomatis mempertinggi frekuensi dan volume perdagangan. Hasil pengujian tersebut sejalan dengan Mardiyah dan Najib (2005) yang menemukan volume perdagangan mengalami peningkatan signifikan sebelum publikasi laporan keuangan dengan setelah pengumuman laporan keuangan.

Terkait abnormal return, Lai et al. (2010) menemukan bahwa perusahaan yang menerapkan IFR dengan tingkat transparansi informasi yang tinggi dan tepat waktu cenderung mempunyai abnormal return yang lebih besar dan harga saham bergerak lebih cepat. Sehingga akan ada perbedaan volume perdagangan dan abnormal return antara sebelum dan sesudah publikasi melalui IFR.

Hal tersebut didukung oleh penelitian Damayanti (2012) tentang reaksi pasar yang diukur melalui abnormal return saham, antara perusahaan yang menerapkan IFR dan yang tidak menerapkan IFR. Hasil pengujian menunjukan terdapat perbedaan abnormal return yang signifikan antara perusahaan yang menerapkan IFR dibandingkan yang tidak menerapkan IFR. Perusahaan yang menerapkan IFR memiliki abnormal return saham yang lebih tinggi daripada yang tidak menerapkan IFR.

IFR yang memungkinkan perusahaan mempublikasikan laporan keuangan secara tepat waktu akan menimbulkan reaksi pasar yang cepat, dampaknya perusahaan akan mempunyai volume perdagangan dan abnormal return yang lebih tinggi dibandingkan sebelum tanggal publikasi. Hal tersebut didasari kandungan informasi yang terdapat pada IFR seperti pengumuman terkait laba, pengumuman deviden ataupun pengumuman pendanaan yang dapat memicu kenaikan nilai volume perdagangan saham dan abnormal return saham. Untuk itu diajukan hipotesis sebagai berikut:

$H_{1}$ : Ada perbedaan volume perdagangan saham perusahaan sebelum dan sesudah Internet Financial Reporting

$\mathrm{H}_{2}$ : Ada perbedaan abnormal return saham perusahaan sebelum dan sesudah Internet Financial Reporting.

\section{METODE PENELITIAN}

Penelitian ini merupakan study event tentang pengaruh publikasi Internet Financial Reporting terhadap volume perdagangan dan abnormal return saham, sehingga populasi dari penelitian ini adalah perusahaan yang terdaftar di Bursa Efek Indonesia pada tahun 2011. Pemilihan sampel 
dilakukan secara purposive sampling dengan kriteria: (1) Perusahaan yang terdaftar di Bursa Efek Indonesia pada tahun 2011 yang menerbitkan laporan keuangan secara lengkap. Penyajian laporan keuangan secara lengkap menurut Keputusan Ketua Bapepam-LK Nomor Kep. 06/PM/2000 tentang Perubahan Peraturan Nomor VIII.G.7 terdiri dari Neraca, Laporan Laba Rugi, Laporan Arus Kas, Laporan Perubahan Ekuitas dan Catatan atas Laporan Keuangan; (2) Mengunggah (upload) laporan keuangan tahunan 2011 melalui website IDX atau melalui website perusahaan yang dapat ditelusuri melalui Yahoo! ataupun Google, sampai dengan tanggal 31 Maret 2012 (batas waktu maksimal yang ditentukan oleh Bapepam untuk penerbitan laporan keuangan yang telah diaudit); (3) Mencantumkan tanggal publikasi laporan keuangan pada website; dan (4) Perusahaan tidak melakukan corporate action selama periode pengamatan yang mungkin dapat mempengaruhi keputusan investor untuk berinvestasi. Berdasarkan kriteria tersebut diperoleh sampel penelitian sebanyak 181 perusahaan sebagaimana dijabarkan dalam Tabel 1 .

Tabel 1. Penentuan Sampel Penelitian

\begin{tabular}{clc}
\hline No & Kriteria & Jumlah \\
\hline 1 & $\begin{array}{l}\text { Perusahaan terdaftar di BEI pada tahun } \\
\end{array}$ & \\
& 2011 \\
2 & $\begin{array}{l}\text { Perusahaan yang tidak mempublikasi } \\
\text { laporan keuangan secara lengkap dan }\end{array}$ & \\
& tepat waktu \\
3 & $\begin{array}{l}\text { Perusahaan yang tidak mencantumkan } \\
\text { tanggal publikasi }\end{array}$ \\
4 & $\begin{array}{l}\text { Perusahaan yang melakukan corporate } \\
\text { action selama periode penelitian }\end{array}$ \\
\hline \multicolumn{1}{c}{ Jumlah sampel penelitian } \\
\hline
\end{tabular}

Sumber: Data sekunder diolah, 2013

Perusahaan yang diklasifikasikan menerapkan IFR sebanyak 181 perusahaan, didominasi oleh industri manufacturing sebanyak 57 perusahaan (31,49\%), dimana didalamnya didominasi sub sektor food and beverages sebanyak 9 perusahaan. Sedangkan sektor real estate and property sebanyak 26 perusahaan (14,36\%) dan sektor credit agencies, securities and insurance sebanyak 22 perusahaan (12,15\%).

Jenis data dalam penelitian ini adalah data sekunder berupa data keuangan perusahaan yang diperoleh dari situs masing-masing perusahaan dan data volume perdagangan diperoleh dari Bursa Efek Indonesia pada tahun 2011 melalui website www.idx.co.id. Data mengenai harga saham diperoleh dari Indonesia Stock Exchange (IDX) tahun 2011.

Penelitian ini menggunakan variabel abnormal return dan volume perdagangan saham untuk mengukur reaksi pasar. Volume perdagangan dan abnormal return saham dihitung dari $t-5$ hingga $t+5$ setelah pengungkapan melalui IFR sebagai event window, bertujuan agar dampak IFR terhadap reaksi pasar dapat diukur secara akurat dan tidak terpengaruh faktor lain yang menyebabkan perubahan keputusan investor.

Trading value activity (TVA) digunakan sebagai ukuran volume perdagangan saham yang digunakan untuk melihat apakah investor menilai sebuah pengumuman sebagai sinyal positif atau negatif, dalam artian apakah informasi tersebut membuat keputusan perdagangan diatas perdagangan normal (Savitri 2001 dalam Budiman dan Supatmi 2008). TVA dapat dihitung dengan rumus:

$$
\text { TVAit }=\frac{\sum_{\text {yang diperdagangkan pada waktu } t}^{\text {saham perusahaan } i}}{\sum \text { saham i yang beredar pada waktu } t}
$$

Setelah TVA dari masing- masing saham diketahui kemudian dihitung rata-rata TVA selama periode pengamatan dengan rumus:

Keterangan:

$$
X T V A t=\frac{\sum T V A i}{n}
$$

$X T V A t=$ Rata-rata TVA pada waktu ke- $t$

$\Sigma T V A i=$ Jumlah TVA pada waktu ke- $t$

$n \quad=$ Jumlah sampel

Abnormal return (return tidak normal) adalah selisih antara return sesungguhnya yang terjadi dengan return ekspektasi (Hartono 2008). Return ekspektasi akan dihitung menggunakan marked adjusted model. Rumus yang digunakan dalam menentukan abnormal return adalah:

$$
A R_{i . t}=R_{i . t}-E\left[R_{i . t}\right]
$$

Dimana:

$E\left(R_{i . t}\right)=a_{i}+\beta_{i .} R_{m . t}+\varepsilon_{i}$

$R_{m . t}=\frac{I H S G_{t}-I H S G_{t-1}}{I H S G_{t-1}} \operatorname{dan} R_{i . t}=\frac{\left[P_{i . t}-P_{i . t-1}\right]}{P_{i . t-1}}$

Keterangan:

$A R_{i . t}=$ return tidak normal (abnormal return) sekuritas ke-i pada periode peristiwa ke- $t$

$R_{i . t}=$ return sesungguhnya yang terjadi pada sekuritas ke-i pada periode ke- $t$

$E\left[R_{i . t}\right]=$ return ekspektasi sekuritas ke- $i$

$a_{i} \quad=$ intercept sekuritas ke- $i$

$\beta_{i} \quad=$ koefisien beta sekuritas ke- $i$

$\varepsilon_{i}=$ kesalahan residu sekutitas ke- $i$

$R_{m . t}=$ return indeks pasar yang terjadi pada periode peristiwa ke- $t$

$I H S G_{t}=$ indeks harga saham gabungan yang terjadi pada periode peristiwa ke- $t$

$I H S G_{t-1}=$ indeks harga saham gabungan yang terjadi pada periode peristiwa ke- $t$ - 1 
$P_{i . t} \quad=$ harga saham sekuritas ke- $i$ pada periode peristiwa ke- $t$

$P_{i . t-1}=$ harga saham sekuritas ke- $i$ pada periode peristiwa ke $t$ - 1 kecil.

Teknik analisis yang digunakan dalam penelitian ini adalah dengan uji perbedaan rata-rata dengan Wilcoxon Signed Test, karena uji normalitas data dengan menggunakan uji Kolmogorov-Smirnov menunjukkan bahwa nilai signifikansi masing-masing variabel lebih kecil dari 0,05 yang berarti bahwa data tidak berdistribusi normal. Adapun hipotesis statistiknya sebagai berikut:

$H_{0}: \mu_{1}=\mu_{2}$

$H_{a}: \mu_{1} \neq \mu_{2}$

\section{HASIL PENELITIAN DAN PEMBAHASAN}

Gambaran terkait pola pergerakan rata-rata volume perdagangan saham semua sampel akan disajikan melalui Grafik 1. Dari Grafik 1, $t$-5 dan $t$ 4 menunjukkan adanya peningkatan nilai ratarata volume perdagangan saham pada saat menjelang upload IFR. Volume perdagangan saham mengalami penurunan pada $t$-3 namun nilai TVA mencapai puncak tertinggi pada saat $t$ - 2 . Sehari setelah mencapai puncaknya dan pada saat tanggal diunggahnya IFR, rata-rata volume perdagangan saham cenderung mengalami penurunan sampai dengan $t+2$. Artinya, jumlah transaksi yang bertambah sebelum publikasi IFR mengindikasikan adanya kebocoran informasi dari dalam perusahaan, sehingga setelah IFR dipublikasikan momen tersebut sudah hilang dan investor bertransaksi secara normal.

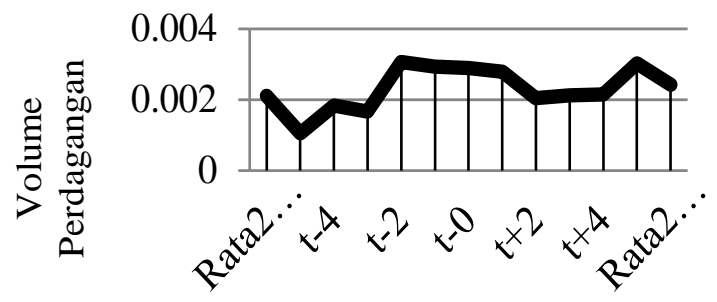

Periode

Sumber: Data sekunder diolah, 2013

\section{Grafik 1. Volume Perdagangan Saham}

Volume perdagangan saham bergerak cukup stabil pada $t+3$ dan $t+4$. Pada saat $t+5$, rata-rata volume perdagangan saham kembali mengalami peningkatan yang drastis, mendekati nilai puncak volume perdagangan saham. Hal ini mengindikasikan adanya perbedaan rata-rata volume perdagangan saham di seputar tanggal upload
IFR. Rata-rata volume perdagangan saham sebelum publikasi senilai 0,002105 dan rata-rata sesudah publikasi senilai 0,002422 membuktikan bahwa reaksi pasar yang diukur dengan variabel volume perdagangan sesudah publikasi lebih tinggi daripada sebelum publikasi IFR.

Hasil ini sejalan dengan penelitian Mardiyah dan Najib (2005) yang menemukan nilai rata-rata volume perdagangan setelah publikasi yang lebih besar dibandingkan sebelum publikasi laporan keuangan. Hal tersebut terjadi karena terdapat sejumlah perusahaan yang dianggap investor memiliki prospek bagus, sehingga menyebabkan perbedaan volume perdagangan yang cukup besar setelah informasi dipublikasikan.

Pergerakan abnormal return saham tertera pada Grafik 2.

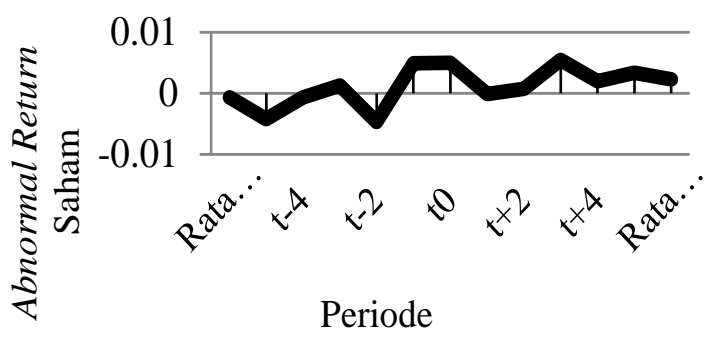

Sumber: Data sekunder diolah, 2013

\section{Grafik 2. Abnormal Return Saham}

Dari Grafik 2 dapat dilihat bahwa rata-rata abnormal return menunjukkan peningkatan pada $t$ - 5 sampai dengan $t$ - 3 yang mampu mencapai nilai positif. Namun pada $t$ - 2 terjadi penurunan yang drastis hingga nilai rata-rata abnormal return mencapai titik terendah. Hal tersebut mengindikasikan selisih ekspektasi yang terjadi kemungkinan disebabkan munculnya informasi yang negatif sebelum IFR dirilis. Sehari sebelum tanggal upload IFR ( $t-1)$ dan pada saat tanggal upload IFR $(t 0)$ kembali menunjukan trend positif.

Pola pergerakan kembali menurun sehari setelah tanggal perusahan mengunggah laporan keuangan melalui internet. Pada $t+2$ rata-rata abnormal return kembali mengalami peningkatan dan pada $t+3$ rata-rata abnormal return mencapai nilai puncaknya. Pergerakan fluktuatif terjadi pada saat $t+4$ dan $t+5$. Hal tersebut mengindikasikan adanya perbedaan rata-rata abnormal return di seputar tangal upload IFR. Rata-rata abnormal return sebelum publikasi senilai 0,000652 dan rata-rata sesudah publikasi senilai 0,002281 membuktikan bahwa reaksi pasar yang diukur dengan variabel abnormal return sesudah publikasi lebih tinggi daripada sebelum publikasi IFR. Hasil temuan tersebut senada dengan penelitian Damayanti (2012) yang menyebutkan terjadi 
kenaikan abnormal return setelah tanggal publikasi, khususnya perusahaan yang menerapkan IFR. Hal tersebut menguatkan bukti terjadinya efisiensi pasar bentuk setengah kuat, yaitu informasi yang dipublikasikan mempengaruhi harga sekuritas dari perusahaan yang mempublikasikan IFR.

Hasil pengujian hipotesis terhadap volume perdagangan saham disajikan dalam Tabel 2. Berdasarkan hasil pengujian Wilcoxon Sign Test tersebut membuktikan bahwa IFR memiliki kandungan informasi yang bermanfaat dalam pengambilan keputusan investor, sehingga pasar bereaksi terhadap informasi tersebut.

Tabel 2. Uji Hipotesis Volume Perdagangan Saham

\begin{tabular}{|c|c|c|c|}
\hline Keterangan & $\mathbf{Z}$ & Asymp Sig & Kesimpulan \\
\hline $\begin{array}{l}\text { Rata-rata } \\
\text { sebelum - Rata- } \\
\text { rata sesudah }\end{array}$ & -1.761 & $0.078 * *$ & $H_{1}$ diterima \\
\hline $\mathrm{TVA}_{-5}-\mathrm{TVA}_{+5}$ & -2.118 & $0.034^{*}$ & $H_{1}$ diterima \\
\hline TVA- $_{4}-\mathrm{TVA}_{+4}$ & -0.616 & 0.538 & $\begin{array}{l}H_{0} \text { tidak dapat } \\
\text { ditolak }\end{array}$ \\
\hline $\mathrm{TVA}_{-3} \quad-\mathrm{TVA}_{+3}$ & -2.667 & $0.008 *$ & $H_{1}$ diterima \\
\hline $\mathrm{TVA}_{-2} \cdot \mathrm{TVA}_{+2}$ & -1.851 & $0.064 * *$ & $H_{1}$ diterima \\
\hline TVA $_{-1} \quad-\mathrm{TVA}_{+1}$ & -0.159 & 0.874 & $\begin{array}{l}H_{0} \text { tidak dapat } \\
\text { ditolak }\end{array}$ \\
\hline
\end{tabular}

Keterangan: *) **) pada tingkat signifikansi $5 \%$ dan $10 \%$

Hasil pengujian hipotesis pertama berdasarkan Tabel 2, reaksi pasar yang diukur melalui variabel volume perdagangan saham terlihat adanya perbedaan yang signifikan pada sebelum dan sesudah tanggal perusahaan mengunggah IFR. Hal ini terlihat ada perbedaan signifikan rata-rata sebelum dengan rata-rata sesudah tanggal upload IFR, $t-5$ dengan $t 5, t-3$ dengan $t+3$ dan $t$ - 2 dengan $t+2$.

Hasil pengujian ini mengindikasikan bahwa pasar bereaksi terhadap penerapan Internet Financial Reporting yang dilakukan perusahaan. Terbuktinya hipotesis pertama ini memunculkan dugaan bahwa sudah banyak investor yang memahami dan merespon manfaat IFR yang diterapkan perusahaan, sehingga terdapat perbedaan volume perdagangan saham sebelum dan sesudah perusahaan mengunggah IFR. Hasil penelitian ini sejalan dengan pengujian Mardiyah dan Najib (2005) yang menemukan volume perdagangan mengalami peningkatan signifikan sebelum publikasi laporan keuangan dengan setelah pengumuman laporan keuangan.

Pengujian hipotesis kedua terkait reaksi pasar menggunakan variabel abnormal return saham dapat dijelaskan melalui Tabel 3. Dari pengujian tersebut, maka dapat diinterpretasikan adanya perbedaan yang signifikan nilai abnormal return saham pada sebelum dan sesudah tanggal perusahaan mengunggah IFR. Hal ini dibuktikan dengan adanya perbedaan signifikan $t$ - 5 dengan $t+5$ dan $t-1$ dengan $t+1$. Perbedaan tersebut mengindikasikan bahwa pasar bereaksi terhadap penerapan Internet Financial Reporting yang dilakukan perusahaan.

Tabel 3. Uji Hipotesis Abnormal Return Saham

\begin{tabular}{|c|c|c|c|}
\hline Keterangan & $\mathbf{Z}$ & Asymp Sig & Kesimpulan \\
\hline $\begin{array}{l}\text { Rata-rata } \\
\text { sebelum - Rata- } \\
\text { rata sesudah }\end{array}$ & -1.325 & 0.185 & $\begin{array}{l}H_{0} \text { tidak dapat } \\
\text { ditolak }\end{array}$ \\
\hline $\mathrm{AR}_{-5}-\mathrm{AR}_{+5}$ & -2.393 & $0.017 *$ & $\mathrm{H}_{2}$ diterima \\
\hline $\mathrm{AR}_{-4}-\mathrm{AR}_{+4}$ & -1.046 & 0.295 & $\begin{array}{l}H_{0} \text { tidak dapat } \\
\text { ditolak }\end{array}$ \\
\hline $\mathrm{AR}_{-3}-\mathrm{AR}_{+3}$ & -0.606 & 0.544 & $\begin{array}{l}\text { Hotidak dapat } \\
\text { ditolak }\end{array}$ \\
\hline $\mathrm{AR}_{-2}-\mathrm{AR}_{+2}$ & -1.461 & 0.144 & $\begin{array}{l}H_{0} \text { tidak dapat } \\
\text { ditolak }\end{array}$ \\
\hline $\mathrm{AR}_{-1}-\mathrm{AR}_{+1}$ & -1.941 & $0.052 * *$ & $\mathrm{H}_{2}$ diterima \\
\hline
\end{tabular}

Perbedaan abnormal return secara signifikan yang terjadi pada $t-5$ dengan $t+5$ dan $t-1$ dengan $t+1$, mengindikasikan adanya selisih ekspektasi investor sebelum informasi melalui IFR dirilis dengan sesudah dirilis. Pada lima hari setelah perusahaan mengunggah laporan keuangan melalui internet, investor merasa harga saham sudah cenderung stabil pada nilai positif. Ada kemungkinan investor memahami manfaat IFR, sehingga bersedia membeli saham dengan harga tinggi sekalipun.

Sedangkan respon pasar pada $t-1$ dan $t+1$, muncul dugaan adanya kebocoran informasi dari dalam perusahaan (insider information) sehingga pasar mulai bereaksi. Pada sehari sebelum tanggal perusahaan mengunggah IFR, nilai abnormal return meningkat drastis dari nilai negatif terendah menuju nilai positif. Realisasi yang terjadi di pasar, sehari setelah upload IFR nilai abnormal return kembali mengalami penurunan yang cukup tajam.

Sebagaimana ditunjukkan pada Grafik 2, pada saat $t$-4 dengan $t+4, t-3$ dengan $t+3$ dan $t$ - 2 dengan $t+2$ konsisten menunjukkan peningkatan abnormal return saham, yang mengindikasikan upload IFR berpengaruh terhadap abnormal return saham, namun tidak signifikan. Ada dugaan munculnya ketidakpastian informasi untuk investor sehingga beberapa kelompok investor kurang memperdulikan informasi keuangan yang diunggah melalui internet. Adapun pada $t+2, t+3$ dan $t+4$ setelah perusahaan mengunggah IFR masih menunjukan nilai rata-rata abnormal return positif sehingga dapat dikatakan bahwa pasar masih bereaksi dengan adanya IFR. 
Hasil penelitian ini mendukung penelitian Lai et al. (2010) yang menemukan bahwa perusahaan yang menerapkan IFR dengan tingkat transparansi informasi yang tinggi dan tepat waktu cenderung mempunyai abnormal return yang lebih besar dan harga saham bergerak lebih cepat. Penelitian ini juga mendukung penelitian Damayanti (2012) yang menemukan adanya perbedaan signifikan abnormal return perusahaan yang menerapkan IFR dengan yang tidak menerapkan IFR di seputar tanggal IFR dirilis.

\section{KESIMPULAN DAN SARAN}

Penerapan IFR terbukti mendorong terjadinya reaksi pasar yang diukur melalui variabel volume perdagangan saham dan abnormal return saham. Rata-rata volume perdagangan dan $a b$ normal return berbeda secara signifikan sebelum perusahaan mengunggah IFR dengan sesudah perusahaan mengunggah IFR. Penelitian ini juga menemukan adanya nilai rata-rata volume perdagangan saham dan abnormal return setelah publikasi yang lebih besar dibandingkan sebelum publikasi IFR. Hal tersebut menguatkan bukti terjadinya efisiensi pasar bentuk setengah kuat di Indonesia, yaitu informasi yang dipublikasikan mempengaruhi harga sekuritas dari perusahaan yang mempublikasikan IFR (Hartono 2008).

Hasil penelitian ini sejalan dengan pengujian Mardiyah dan Najib (2005) yang menemukan volume perdagangan mengalami peningkatan signifikan sebelum publikasi laporan keuangan dengan setelah pengumuman laporan keuangan. Selain itu juga mendukung penelitian Lai et al. (2010) yang menemukan abnormal return yang lebih besar dan harga saham bergerak lebih cepat pada perusahaan yang menerapkan IFR.

Penelitian ini memberikan kontribusi kepada investor agar memanfaatkan IFR dalam pengambilan keputusan di pasar modal sehingga memperoleh keuntungan. Terbuktinya perbedaan reaksi pasar dalam penelitian ini diharapkan mendorong perusahaan untuk mempraktekkan IFR secara optimal dan tepat waktu sebagai sarana pelaporan informasi yang transparan dan cepat. Selain itu, masih banyaknya perusahaan yang terlambat mempublikasikan IFR diharapkan mendorong regulator yaitu BapepamLK untuk menegakkan aturan yang sudah dibuat.

Penelitian ini mempunyai keterbatasan yaitu mengabaikan adanya faktor makro ekonomi dan mikro ekonomi seperti inflasi, kondisi ekonomi, kebijakan pemerintah dan perbedaan variasi industri di Indonesia yang mungkin dapat mempengaruhi hasil penelitian. Saran untuk penelitian mendatang, sebaiknya penelitian mendatang fokus pada satu sektor industri untuk dapat menggambarkan dampak IFR secara lebih jelas terhadap industri tertentu. Selain itu menambah variabel lain yang berkaitan dengan reaksi pasar, misal harga saham atau return saham.

\section{DAFTAR PUSTAKA}

Institute for Economic and Financial Research (2012), Indonesian Capital Market Directory 2011.

Abdelsalam, O. H., Bryant, S. M., dan Street, D. L. (2007). An Examination of the Comprehensiveness of Corporate Internet Reporting Provided by London-Listed Companies. Journal of International Accounting Research, 6(2).

Ashbaugh, H., Johnstone, K., and Warfield, T. (1999). Corporate Reporting on the Internet. Accounting Horizons, 13(3), 241-257.

Almilia, Luciana Spica (2009). Analisa Kualitas Isi Financial and Sustainability Reporting pada Website Perusahaan go Publik di Indonesia, Seminar Nasional Aplikasi Teknologi Informasi 2009 (SNATI 2009).

Budiman, Ferry dan Supatmi (2008). Pengaruh Pengumuman Indonesia Sustainability Reporting Award (ISRA) terhadap Abnormal Return dan Volume Perdagangan Saham. Simposium Nasional Akuntansi XII Palembang.

Chariri, A. dan Lestari, H. S. (2005). Analisis Faktor-Faktor yang Mempengaruhi Pelaporan Keuangan Melalui Internet (Internet Financial Reporting) dalam Website Perusahaan, Fakultas Ekonomi Universitas Diponegoro.http://eprints.undip.ac.id/2398/1/I FR_research.pdf, 15 September 2012.

Damayanti, Kartika (2012). Internet Financial Reporting (IFR) dan Reaksi Pasar, Call for Paper 2012 Fakultas Ekonomika dan Bisnis Universitas Kristen Satya Wacana.

Hargyantoro, Febrian (2010). Pengaruh Internet Financial Reporting dan Tingkat Pengungkapan Informasi Website terhadap Frekuensi Perdagangan Saham Perusahaan, Universitas Diponegoro. http://eprints.undip. ac.id/22801/1/SKRIPSI_FINAL.pdf. 9 September 2012 .

Hartono, Jogiyanto (2008). Teori Portofolio dan Analisis Investasi, BPFE Yogyakarta.

Keputusan Ketua Bapepam-LK No. Kep-346/BL/ 2011 tanggal 5 Juli 2011.

Keputusan Ketua Bapepam-LK Nomor Kep. 06/ PM/2000 tentang Perubahan Peraturan Nomor VIII.G.7 tanggal 30 Desember 2010. 
Anuragabudhi, I. dan Purwaningsih, A. (2008). Analisis Kinerja Keuangan Perusahaan Sebelum dan Setelah Stock Split: Studi Empiris pada Perusahaan Manufaktur yang Terdaftar di Bursa Efek Jakarta. Modus Jurnal Ekonomi dan Bisnis, Vol. 20. No.1.

Internet World Stats (2011). World Internet Usage and Populations Statistic 2011, http://www. internetworldstats.com/stats3.htm. 9 September 2012.

Lai, S. C., Lin, C., Lee, H. C., and Wu, F. H. (2010). An Empirical Study of the Impact of Internet Financial Reporting on Stock Prices, The International Journal of Digital Accounting Research ,10, 1-26.

Mardiyah, A. A. dan Najib, A. (2005). Perbedaan Publikasi Laporan Keuangan terhadap Volume Perdagangan Saham di Bursa Efek
Jakarta. Simposium Riset Ekonomi II, Ikatan Sarjana Ekonomi Indonesia.

McLeod, Raymond Jr. (2007), Management Information Systems. Pearson/Prentice Hall. United States.

Octavina, Devita Nurmala (2008). Analisis Abnormal Return dan Aktivitas Volume Perdagangan Saham di Seputar Pengumuman Deviden. Universitas Islam Negeri Malang. http://lib. uin-malang.ac.id/thesis/fullchapter/04610090devita-normala-octavina. pdf. 11 September 2012.

Wibisono, Gunawan (2011). Internet Financial Reporting dan Tempelan Multimedia pada Statement Keuangan Elektronik. Majalah Triwulan, Fakultas Ekonomika dan Bisnis Universitas Gajah Mada, Edisi 10/November: 26-27 